\title{
Assessing Forest Ecosystems across the Vertical Edge of the Mid-Latitude Ecotone Using the BioGeoChemistry Management Model (BGC-MAN)
}

\author{
Cholho Song ${ }^{1,2}{ }^{\oplus}$, Stephan A. Pietsch ${ }^{2}$, Moonil Kim ${ }^{2,3}$, Sungeun Cha ${ }^{1,2}{ }^{\oplus}$, Eunbeen Park ${ }^{1}$, \\ Anatoly Shvidenko ${ }^{2}$, Dmitry Schepaschenko ${ }^{2}{ }^{-}$, Florian Kraxner ${ }^{2}{ }^{-1}$ and Woo-Kyun Lee ${ }^{1, *}$ \\ 1 Department of Environmental Science and Ecological Engineering, Korea University, Seoul 02841, Korea; \\ cholhosong@korea.ac.kr (C.S.); tgy2005@korea.ac.kr (S.C.); heyevvin@gmail.com (E.P.) \\ 2 Ecosystems Services and Management, International Institute for Applied Systems Analysis (IIASA), \\ Schlossplatz 1, A-2361 Laxenburg, Austria; pietsch@iiasa.ac.at (S.A.P.); kimml@iiasa.ac.at (M.K.); \\ shvidenk@iiasa.ac.at (A.S.); schepd@iiasa.ac.at (D.S.); kraxner@iiasa.ac.at (F.K.) \\ 3 Environmental GIS/RS Center, Korea University, Seoul 02841, Korea \\ * Correspondence: leewk@korea.ac.kr; Tel.: +82-2-3290-3016
}

Received: 31 May 2019; Accepted: 21 June 2019; Published: 23 June 2019

\begin{abstract}
The mid-latitude ecotone (MLE) — a transition zone between boreal and temperate forests, which includes the regions of Northeast Asia around $30^{\circ}-60^{\circ} \mathrm{N}$ latitudes-delivers different ecosystem functions depending on different management activities. In this study, we assessed forest volume and net primary productivity changes in the MLE of Northeast Asia under different ecological characteristics, as well as various current management activities, using the BioGeoChemistry Management Model (BGC-MAN). We selected five pilot sites for pine (Scots pine and Korean red pine; Pinus sylvestris and P. densiflora), oak (Quercus spp.), and larch forests (Dahurian larch and Siberian larch; Larix gmelinii and L. sibirica), respectively, which covered the transition zone across the MLE from Lake Baikal, Russia to Kyushu, Japan, including Mongolia, Northeast China, and the Korean Peninsula. With site-specific information, soil characteristics, and management descriptions by forest species, we established their management characteristics as natural preserved forests, degraded forests, sandy and cold forest stands, and forests exposed to fires. We simulated forest volume $\left(\mathrm{m}^{3}\right)$ and net primary productivity $\left(\mathrm{Mg} \mathrm{C} \mathrm{ha}^{-1}\right)$ during 1960-2005 and compared the results with published literature. They were in the range of those specified in previous studies, with some site-levels under or over estimation, but unbiased estimates in their mean values for pine, oak, and larch forests. Annual rates of change in volume and net primary productivity differed by latitude, site conditions, and climatic characteristics. For larch forests, we identified a high mountain ecotype which warrants a separate model parameterization. We detected changes in forest ecosystems, explaining ecological transition in the Northeast Asian MLE. Under the transition, we need to resolve expected problems through appropriate forest management and social efforts.
\end{abstract}

Keywords: net primary productivity (NPP); growing stock volume (GSV); Mid-Latitude Ecotone (MLE); BioGeoChemistry Management Model (BGC-MAN); process-based ecosystem model

\section{Introduction}

Forest ecosystems have experienced changes owing to climate change and anthropogenic pressure [1,2], and these changes are particularly rapid in areas with a sensitive ecosystem structure and high population density. In addition, forest degradation, deforestation, and desertification are the main issues that threaten sustainable terrestrial ecosystems, therefore maintaining ecological productivity is important [3]. The northern mid-latitude region (MLR), which is located between $30^{\circ}$ 
and $60^{\circ} \mathrm{N}$ latitudes with various land covers and a lot of human activities, including the mid-latitude ecotone (MLE), is a transition zone between forests and drylands [4-6]. In Eurasia, dense vegetation is distributed along the MLE in regions such as Northeast Asia, Siberia, and Europe, however, drylands also exist in Mongolia, Central Asia, and the Mediterranean region [7,8].

Forests in the MLE consist of boreal and temperate forests, and form a belt connecting the Far East and Europe. This forest belt has important roles in maintaining ecological sustainability and preventing the expansion of drylands. The Northeast Asian MLE, including Korea, China, Japan, and Mongolia, has faced environmental changes during the past decades and will be affected by future climate change [9]. Through the forests of Mongolia and China, the boreal forests of Russia near Lake Baikal and Siberia are connected to the temperate forests in China and the Korean Peninsula [10]. Along this connection, each nation has different forest management issues and environmental conservation regimes.

Temperate forests in South Korea and Japan were restored during the 1960s to 1970s, and now both countries have successful restoration outcomes, with the aim of sustainable forest management [11]. As a case in point, the forest growing stock volume (GSV) in South Korean forests was $10.5 \mathrm{~m}^{3} / \mathrm{ha}^{2}$ in 1952, and it reached $100.4 \mathrm{~m}^{3} /$ ha in 2007 [12]. However, forests in North Korea have suffered from deforestation and forest degradation due to logging for food and fuel production [13,14]. There are some differences in reports on the extent of deforestation in North Korea; the deforested areas there are estimated to have ranged between 1.2 million ha and 2.5 million ha during the late $1980 \mathrm{~s}$ to 2000s [15]. These differences are also represented in the forests' net primary productivity (NPP) as a negative carbon budget in North Korea [16]. Temperate forests were changed to boreal forests in China, Northern Mongolia, and Russia near Lake Baikal. North China and Inner-Mongolia are widely known as regions facing ongoing deforestation and land degradation [17], but the Chinese and Mongolian governments strive to recover their forest ecosystems to secure ecological benefits [18-20], whereas, the forests near Lake Baikal and around the MLE have suffered natural or anthropogenic forest fire [21]. There is great uncertainty in measuring the effect of fire in boreal forests; one estimate revealed that $2.9 \%$ of Russian boreal forest loss was caused by forest fires [22].

Therefore, forest management regimes in the Northeast Asian MLE can be summarized as: (1) well-restored and managed areas in South Korea and Japan; (2) land degradation in North Korea; (3) semi-arid and new plantation in China and Mongolia; and (4) cold temperature with forest fire in Russia. The complexity of the management regimes of different countries leads to different forest statuses. NPP and GSV can represent the effects of these differences, and many modeling approaches were applied in the MLE of Northeast Asia using Flux data, Moderate Resolution Imaging Spectroradiometer-Leaf Area Index (MODIS-LAI), Boreal Ecosystem Productivity Simulator (BEPS), Vegetation Integrative Simulator for Trace gases (VISIT), MAPSS-CENTURY1 (MC1), and Biome-BioGeoChemistry (Biome-BGC) [15,16,23-27]. Forest fluxes were calculated from data obtained from field surveys, but such data were procured at different times and locations [10,24]. Therefore, the use of forest fluxes to understand different management regimes has limitations. Applying models can be the alternative to overcome the spatio-temporal limits of the fluxes. Both satellite-based and process-based ecosystem models were applied to simulate productivities in the Northeast Asian MLE [15,16,28-30]. However, these modeling approaches had limitations in reflecting management details because of different parametrizations and representations of ecological processes and spatio-temporal data limitations.

Our synthetic study elucidates the process of applying the BioGeoChemistry Management Model (BGC-MAN) in the MLE of Northeast Asia. The BGC-MAN, a modified mechanistic biogeochemical model, extends simulations into forest management options in certain forest stands. The model was tested in European forests but has not yet been tested in the MLE of Northeast Asia [31-34]. We assessed past changes in NPP and GSV in the MLE under different environmental characteristics, as well as under various current management activities, using the BGC-MAN. We selected representative forest stands in the MLE of Northeast Asia from literature and assessed changes to the ecosystem and model uncertainties from the simulated results. 


\section{Materials and Methods}

\subsection{Applying BGC-MAN}

BGC-MAN is a process-based ecosystem model, and the model also has the modules to apply forest management activities, so different forest ecosystem and management activities were analysed by BGC-MAN [31-34]. This process-based model requires more than 50 inputs, with daily weather data, bio-physical information, species characteristics of the forest stand, and site information. The model calculates different combinations by the climatic variables (e.g., daily weather data, solar radiation, vapor pressure, precipitation), bio-physical status (e.g., aspects, elevation, and soil and nitrogen characteristics), and species characteristics (e.g., leaf area index (LAI), stomatal conductance, carbon nitrogen ratio). From photosynthesis, the self-initialized model generates gross primary productivity (GPP), NPP, and the carbon allocation of the vegetation's carbon pools, including respirations.

The working steps for applying BGC-MAN in the MLE of Northeast Asia start from selecting study sites. Under the limited carbon flux sites and temporal availability, the study sites were selected based on the literature review. From the literature, we can figure out dominant tree species as well as the bio-physical status and management history of forest stands. To run the model, missing data and parameters were collected and adjusted by geo-spatial analysis and previous BGC-MAN studies in Europe. In addition, we adopted daily weather data from 1951 to 2005 to find current changes of the forest ecosystem. After that, we simulated forest volume $\left(\mathrm{m}^{3}\right)$ and NPP $\left(\mathrm{Mg} \mathrm{C} \mathrm{ha}^{-1}\right)$. We checked the results with different literature and general trends among the study regions.

\subsection{Study Sites}

To cover the MLE in Northeast Asia, we selected five pilot sites from each of the southern parts of the selected sites, including oak (Quercus spp.), pine (Pinus sylvestris and Pinus Densiflora), and larch (Larix Mongolica and Larix Sibirica) stands [35-38] (Figure 1). The study sites were distributed along latitudinal (vertical) transects. They were also located near the borders of forests with other land covers and different forest densities [7,39]. In addition, various human effects due to different management of forest activities were found from literature [6,40]. Therefore, this region has ecological and socio-economic transitions that vary according to each tree species and nation.

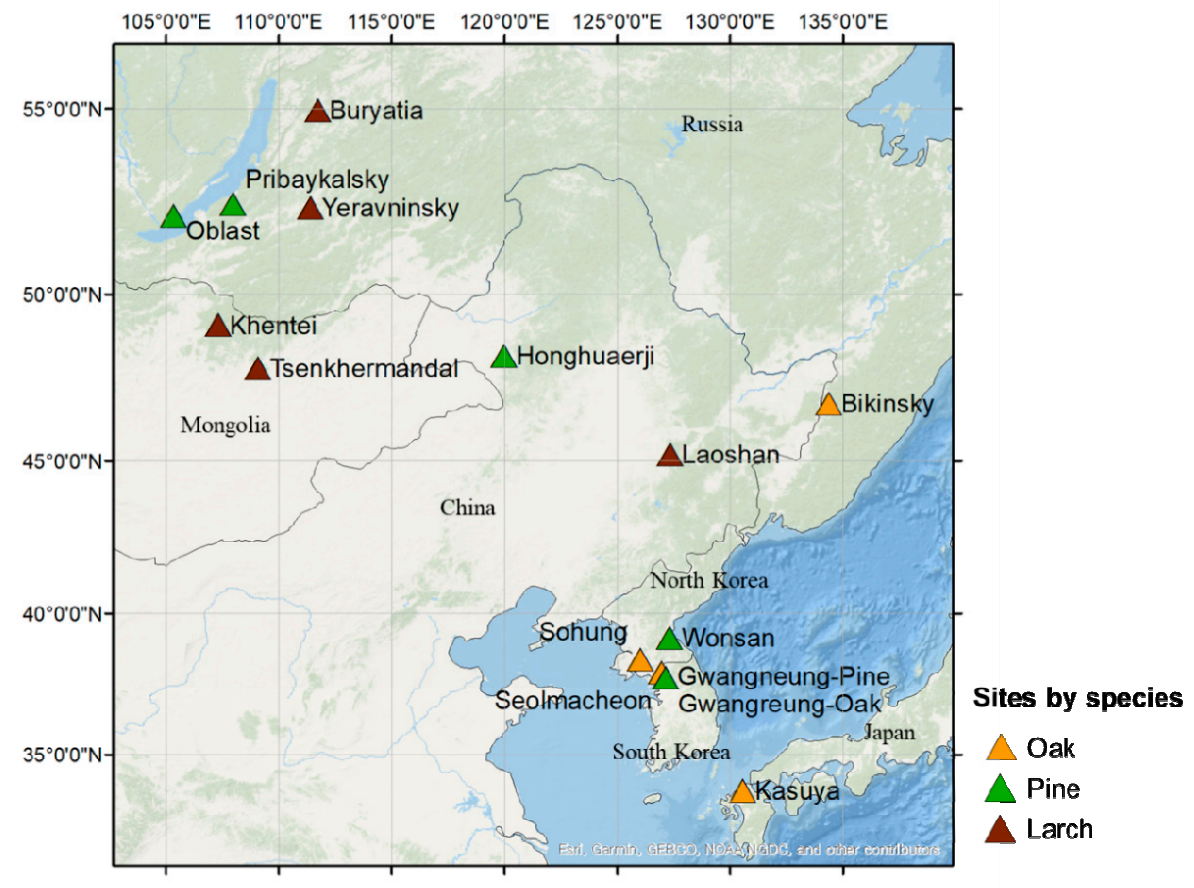

Figure 1. Study sites (oak, pine, and larch stands) along the mid-latitude ecotone (MLE) of Northeast Asia. 
Oak forests are distributed in the Korean Peninsula, Japan, and Far East Russia. The Kasuya stand, located in Kyushu, Japan, is one of 34 long-term monitoring forest sites of JaLTER (Japan Long Term Ecological Research Network), so forest disturbance has been very limited here in comparison with the other forests $[35,41]$. Based on the literature review, its forest age is around 140 years. The Gwangneung stand in South Korea has been well-preserved as it is a national arboretum, therefore it has a very old forest stand age, around 80-200 years [16,36,42]. In addition, many field studies by the National Institute of Forest Science (NIFoS), as well as individual previous studies, have monitored forest changes. The Seolmacheon stand in South Korea was also recently added to the AsiaFlux network [43,44]. This forest stand is young, aged around 20-40 years, and some forest hydrology experiments have been conducted here. Detailed forest characteristics of the Sohung stand in North Korea, one of the degraded and partially restored areas, were assumed based on a previous case study for Reducing Emission from Deforestation and land Degradation (REDD+) [45]. Bikinsky is located in Far East Russia, near the border of China, and forest fires are common in the surrounding forests [46].

Pine forests are widespread around the Korean Peninsula, Northeast China, and near Lake Baikal. Gwangneung also has old protected pine forests for royal timber production, and presently has well-preserved natural forests [38,47,48]. Its forest age is more than 80 years. Wonsan, which is located on the east coast of North Korea, is one of the focus areas for restoring deforested North Korean forests $[11,49]$. Honghuaerji forest is located in a sandy area with a relatively young forest stand age. This site was established by Chinese government projects to restore the sandy lands and reduce soil desertification [50,51]. One of the Russian forest stands, named Oblast, is located on the western side of Lake Baikal near Irkutsk, and the other, named Pribaykalsky, is located on its eastern side. Both forest stands experience forest fires and they are some of the coldest among the pine tree sites [46].

The larch trees in Laoshan, China were planted in 1969 as an experimental forest, and various studies have been conducted in this site [26,37]. In Mongolia, the Tsenkhermandal and Khentei sites were selected for our simulation. Tsenkhermandal is located in the high mountains with a 110-year-old forest, and the Khentei site represents typical Mongolian larch forests near Ulaanbaatar. There have been different estimates of its forest age from previous studies, but it is estimated to be as old as 64-146, according to tree ring surveys [52-54]. Yeravninsky is a 100-year-old forest and is located on the eastern side of Lake Baikal across the mountains there. Buryatia is the northernmost site and comprises a 100-year-old high mountain forest. Both forest stands experience forest fires [46]. From these previous studies, a site information table, especially including information on species, forest age, and location with management history, was constructed (Table 1).

To add more details, site-specific management information and mortality rates were adopted from the previous studies. For the pine forests, a site-specific mortality rate of $1.4 \%$ was applied for the Gwangneung forest [38], but the average mortality rate was 3\% in the other Korean young forests [55]. The average mortality of oak forests in Korea was 1.7-2.0\%, however, it was as high as $4.2 \%$ in some oak stands [55]. We assumed that the mortality of old forest stands was lower than average but allowed a higher mortality rate for young forests. In the case of Russian forests, we applied an average mortality rate of $0.6 \%$ through calculations from data on growth and productivity [46]. Similarly, the mortality rate of larch forests from the Korean Peninsula was applied to the young forests in China. This value was $5.0-5.6 \%$ in L. kaempferi. For the other forests, a mortality rate of $0.2-0.3 \%$ was applied.

We set management characteristics as: (1) well-restored and managed areas in South Korea and Japan; (2) land degradation in North Korea; (3) semi-arid and new plantation in China and Mongolia; and (4) cold temperature with forest fires in Russia. Following these differences, the model adopted options of planting, clear-cutting, natural preservation, and logging. From the forest age, we initialized the planting and clear-cutting options for modeling to fit the respective management history. For example, many sites in South Korea and Japan were planted and naturally preserved if these were their historical management strategies, but we assumed clear-cutting in North Korea, following their history of deforestation. 
Table 1. Site-specific information, including mortality rates, fire fractions, and applied management options.

\begin{tabular}{|c|c|c|c|c|c|c|c|c|c|c|c|c|c|c|c|}
\hline \multirow{2}{*}{$\begin{array}{l}\text { Classes } \\
\text { Species }\end{array}$} & \multicolumn{5}{|c|}{ Oak Forest Stands } & \multicolumn{5}{|c|}{ Pine Forest Stands } & \multicolumn{5}{|c|}{ Larch Forest Stands } \\
\hline & $\begin{array}{c}\text { Quercus } \\
\text { acuta }\end{array}$ & $\begin{array}{l}\text { Quercus } \\
\text { serrata }\end{array}$ & $\begin{array}{c}\text { Quercus } \\
\text { variabilis }\end{array}$ & $\begin{array}{l}\text { Quercus } \\
\text { mongolica }\end{array}$ & $\begin{array}{l}\text { Quercus } \\
\text { mongolica }\end{array}$ & $\begin{array}{c}\text { Pinus } \\
\text { densiflora }\end{array}$ & $\begin{array}{c}\text { Pinus } \\
\text { densiflora }\end{array}$ & $\begin{array}{c}\text { Pinus } \\
\text { sylvestris }\end{array}$ & $\begin{array}{c}\text { Pinus } \\
\text { sylvestris }\end{array}$ & $\begin{array}{c}\text { Pinus } \\
\text { sylvestris }\end{array}$ & $\begin{array}{c}\text { Larix } \\
\text { gmelinii }\end{array}$ & $\begin{array}{c}\text { Larix } \\
\text { sibirica }\end{array}$ & $\begin{array}{l}\text { Larix } \\
\text { sibirica }\end{array}$ & $\begin{array}{l}\text { Larix } \\
\text { gmelinii }\end{array}$ & $\begin{array}{c}\text { Larix } \\
\text { gmelinii }\end{array}$ \\
\hline Types & Evergreen & Deciduous & Deciduous & Deciduous & Deciduous & Evergreen & Evergreen & Evergreen & Evergreen & Evergreen & Deciduous & Deciduous & Deciduous & Deciduous & Deciduous \\
\hline Location & Kasuya & $\begin{array}{l}\text { Gwang- } \\
\text { neung }\end{array}$ & $\begin{array}{l}\text { Seolma- } \\
\text { cheon }\end{array}$ & Sohung & Bikinsky & $\begin{array}{l}\text { Gwang- } \\
\text { neung }\end{array}$ & Wonsan & $\begin{array}{l}\text { Hong- } \\
\text { huaerji }\end{array}$ & Oblast & $\begin{array}{l}\text { Pribay- } \\
\text { kalsky }\end{array}$ & Laoshan & $\begin{array}{l}\text { Tsenkher- } \\
\text { mandal }\end{array}$ & Khentei & $\begin{array}{l}\text { Yeravnin- } \\
\text { sky }\end{array}$ & Buryatia \\
\hline Nation ${ }^{1}$ & JPN & ROK & ROK & DPRK & RUS & ROK & DPRK & $\mathrm{CHN}$ & RUS & RUS & $\mathrm{CHN}$ & MNG & MNG & RUS & RUS \\
\hline Longitude $\left({ }^{\circ}\right)$ & 130.550 & 127.149 & 126.955 & 126.032 & 134.373 & 127.162 & 127.320 & 119.993 & 105.334 & 107.985 & 127.340 & 109.068 & 107.316 & 111.411 & 111.728 \\
\hline Latitude $\left({ }^{\circ}\right)$ & 33.650 & 37.750 & 37.939 & 38.391 & 46.770 & 37.748 & 39.149 & 48.200 & 52.185 & 52.504 & 45.200 & 47.835 & 49.100 & 52.397 & 54.960 \\
\hline Elevation (m) & 355 & 340 & 293 & 169 & 160 & 425 & 481 & 836 & 730 & 620 & 370 & 1797 & 1021 & 922 & 1612 \\
\hline Aspect (\%) & $\mathrm{E}$ & NW & NW & $\mathrm{N}$ & $\mathrm{s}$ & SW & $\mathrm{N}$ & sW & $\mathrm{NE}$ & SW & sW & $\mathrm{N}$ & NW & NW & $\mathrm{N}$ \\
\hline Slope (\%) & 15 & 14 & 15 & 21 & 15 & 19 & 21 & 1 & 26 & 25 & 6 & 24 & 8 & 32 & 34 \\
\hline Sand (\%) & 42 & 50 & 52 & 42 & 15 & 50 & 42 & 89 & 65 & 55 & 37 & 31 & 45 & 34 & 38 \\
\hline Silt (\%) & 36 & 13 & 25 & 36 & 48 & 45 & 36 & 6 & 25 & 37 & 45 & 36 & 31 & 33 & 31 \\
\hline Clay (\%) & 22 & 37 & 23 & 22 & 37 & 5 & 22 & 5 & 10 & 8 & 18 & 33 & 24 & 23 & 21 \\
\hline Soil depth (m) & 1.00 & 1.00 & 1.00 & 1.00 & 1.60 & 1.00 & 1.00 & 1.00 & 0.80 & 0.95 & 1.00 & 0.90 & 1.00 & 1.00 & 0.60 \\
\hline East horizon $\left({ }^{\circ}\right)$ & 5 & 0 & 7 & 26 & 32 & 0 & 0 & 31 & 6 & 35 & 3 & 16 & 16 & 18 & 5 \\
\hline West horizon $\left({ }^{\circ}\right)$ & 60 & 18 & 0 & 54 & 10 & 5 & 6 & 0 & 10 & 10 & 2 & 4 & 8 & 0 & 2 \\
\hline Forest age & 140 & $80-200$ & $20-40$ & - & 80 & $80+$ & - & $40-60$ & 95 & 60 & $40-50$ & 110 & $60-150$ & 100 & 100 \\
\hline Mortality $(\%)^{2}$ & $1.7-2.0$ & $1.7-2.0$ & $2.0+$ & $2.0+$ & $1.7-2.0$ & $1.4+$ & $1.4-3.0$ & $1.4-3.0$ & 0.7 & $0.8-2.0$ & $5.0-5.6$ & 0.2 & $0.2-0.3$ & $0.2-0.3$ & $0.2-0.3$ \\
\hline Fire fraction $(\%)$ & - & - & - & - & 0.005 & - & - & - & 0.25 & 0.15 & & 0.15 & - & 0.08 & 0.08 \\
\hline Options $^{3}$ & $\mathrm{P}, \mathrm{N}$ & $\mathrm{P}, \mathrm{N}$ & $\mathrm{C}, \mathrm{P}, \mathrm{N}$ & C, P, L & $\mathrm{P}, \mathrm{N}$ & $\mathrm{C}, \mathrm{P}, \mathrm{N}$ & C, P, L & $\mathrm{P}, \mathrm{N}$ & $\mathrm{P}, \mathrm{N}$ & $\mathrm{P}, \mathrm{N}$ & $\mathrm{C}, \mathrm{P}, \mathrm{N}$ & $\mathrm{P}, \mathrm{N}$ & $\mathrm{P}, \mathrm{N}$ & $\mathrm{P}, \mathrm{N}$ & $\mathrm{P}, \mathrm{N}$ \\
\hline
\end{tabular}

and Kim et al. (2017), but also followed site-specific information. ${ }^{3}$ Options represent historic intervention in certain forest stands (P: Planting, C: Clear-cutting, N: Naturally preserved,

L: Logging). 


\subsection{Data Processing}

To generate sufficient bio-physical data, which is required for running the BGC-MAN (Table 2), we supplemented the data with global scale GIS data, such as the Shuttle Radar Topography Mission (STRM) and Harmonized World Soil Database (HWSD). For the nitrogen deposition values and pre-industrialization and current values, we adopted global modeling results [56,57]. Parameters of nitrogen fixation were applied from several previous studies, which suggested different nitrogen fixation values of mature oak forests (12.1-14.0 $\mathrm{N} \mathrm{kg} \mathrm{ha}^{-1}$ year $\left.^{-1}\right)$, pine (0.3-3.2 $\mathrm{N} \mathrm{kg} \mathrm{ha}^{-1}$ year $^{-1}$ ), and mixed larch hardwood (0.6-4.9 $\mathrm{N} \mathrm{kg} \mathrm{ha}^{-1}$ year $^{-1}$ ) [58-60]. For the larch forest, we followed previous studies, with consideration of the nitrogen fixation value from a mixture of western white pine and western larch $[60,61]$. We adopted parameters for species characteristics from Europe (the west side of the MLE), but we also adjusted some of the carbon and nitrogen allocation, as well as night time freezing temperature values [10,33,62].

Table 2. Species characteristics for running BioGeoChemistry Management (BGC-MAN).

\begin{tabular}{|c|c|c|c|c|}
\hline Parameters & Units & Oak & Pine & Larch \\
\hline Annual leaf and fine root turnover fraction & year $^{-1}$ & 1.0 & 0.3 & 1.0 \\
\hline Annual live wood turnover fraction & year $^{-1}$ & 0.7 & 0.3 & 0.7 \\
\hline Annual whole-plant mortality fraction & year $^{-1}$ & 0.008 & 0.180 & 0.050 \\
\hline Annual fire mortality fraction & year $^{-1}$ & 0.017 & 0.700 & 0.056 \\
\hline New fine root C:new leaf C & ratio & 1.0 & 0.523 & $0.8 \sim 1.2$ \\
\hline New stem C:new total wood C & ratio & 1.29 & 2.5 & $1.2 \sim 2.2$ \\
\hline New live wood C:new total wood C & ratio & 0.120 & 0.059 & 0.1 \\
\hline New coarse root C:new stem C & ratio & 0.250 & 0.290 & 0.23 \\
\hline Current growth proportion & ratio & 0.5 & 0.5 & 0.5 \\
\hline $\mathrm{C}: \mathrm{N}$ of leaves & $\mathrm{kgC} / \mathrm{kgN}$ & 26.9 & 33.1 & $25.8 \sim 27$ \\
\hline $\mathrm{C}: \mathrm{N}$ of leaf letters & $\mathrm{kgC} / \mathrm{kgN}$ & 63.3 & 132.0 & 111.9 \\
\hline $\mathrm{C}: \mathrm{N}$ of fine roots & $\mathrm{kgC} / \mathrm{kgN}$ & 73.5 & 38.0 & 42.0 \\
\hline $\mathrm{C}: \mathrm{N}$ of live wood & $\mathrm{kgC} / \mathrm{kgN}$ & 63.5 & 50.0 & 42.0 \\
\hline $\mathrm{C}: \mathrm{N}$ of dead wood & $\mathrm{kgC} / \mathrm{kgN}$ & 450.0 & 1400.0 & 442.0 \\
\hline Leaf litter labile proportion & DIM & 0.200 & 0.257 & 0.390 \\
\hline Leaf litter cellulose proportion & DIM & 0.560 & 0.493 & 0.440 \\
\hline Leaf litter lignin proportion & DIM & 0.240 & 0.250 & 0.170 \\
\hline Fine root labile proportion & DIM & 0.340 & 0.252 & 0.300 \\
\hline Fine root cellulose proportion & DIM & 0.440 & 0.493 & 0.450 \\
\hline Fine root lignin proportion & DIM & 0.220 & 0.253 & 0.250 \\
\hline Dead wood cellulose proportion & DIM & 0.704 & 0.710 & 0.760 \\
\hline Dead wood lignin proportion & DIM & 0.296 & 0.290 & 0.240 \\
\hline Canopy water interception coefficient & 1/LAI/d & 0.038 & 0.051 & 0.041 \\
\hline Canopy light extinction coefficient & DIM & 0.540 & 0.510 & 0.500 \\
\hline All-sided to projected leaf area ratio & DIM & 2.0 & 2.6 & 2.6 \\
\hline Canopy average specific leaf area & $\mathrm{m}^{2} / \mathrm{kgC}$ & 35.0 & 13.0 & 20.3 \\
\hline Ratio of shaded SLA & DIM & 2.0 & 2.0 & 2.0 \\
\hline Fraction of leaf N in Rubisco & DIM & 0.0880 & 0.0457 & 0.0750 \\
\hline Maximum stomatal conductance & $\mathrm{m} / \mathrm{s}$ & 0.0018 & 0.0010 & 0.0022 \\
\hline Cuticular conductance & $\mathrm{m} / \mathrm{s}$ & 0.00004 & 0.000014 & 0.00001 \\
\hline Boundary layer conductance & $\mathrm{m} / \mathrm{s}$ & 0.005 & 0.09 & 0.008 \\
\hline Leaf water potential & $\mathrm{MPa}$ & $(-0.1)-(-3.5)$ & $(-0.5)-(-2.2)$ & $(-0.7)-(-2.6)$ \\
\hline Vapor pressure deficit & $\mathrm{MPa}$ & $200-2550$ & $50-2500$ & $800-3200$ \\
\hline Night time freezing temperature & C & $(-1)-(-8)$ & $(-2)-(-8)$ & $(-8)-(-20)$ \\
\hline
\end{tabular}


For the daily weather data, we used global climate data at a grid resolution of $0.5^{\circ}$ from the Environmental Policy Integrated Model (EPIC) and modified them through reflecting temperature lapse and horizontal angle of solar radiations using the Mountain Microclimate Simulation Model (MTCLIM) [63-66]. Because the study sites were vertically distributed, climatic characteristics of this region can be described by comparing the northernmost site (Buryatia, Russia) and the southernmost site (Kasuya, Japan) (Figure 2). In Russia, the temperature dropped to $-34.5^{\circ} \mathrm{C}$ in the winter, and climbed to $21.04{ }^{\circ} \mathrm{C}$ in the summer, whereas the temperature varied from $-11.31{ }^{\circ} \mathrm{C}$ to $27.38{ }^{\circ} \mathrm{C}$ in Japan. The climatic variability of the MLE also could be explained by the warmth index (WI) which was used to present the distribution and suitability of vegetation $[67,68]$. The distribution of the WI in Kasuya, Gwangneung, Seolmacheon, Sohung, Bikinsky, Wonsan, Oblast, Pribaykalsky, Laoshan, Tsenkhermandal, Khentei, Yeravninsky, and Buryatia were 97.04, 123.36, 102.09, 142.98, 70.90, 84.12, $68.06,62.89,57.90,85.57,46.84,63.56,55.43$, and 23.26, respectively. In addition, the accumulated precipitation in the sites in Russia and Japan was $30.41 \mathrm{~cm}$ and $157.29 \mathrm{~cm}$, respectively. These differences contributed to different ecological transitions along this the region [5,9].

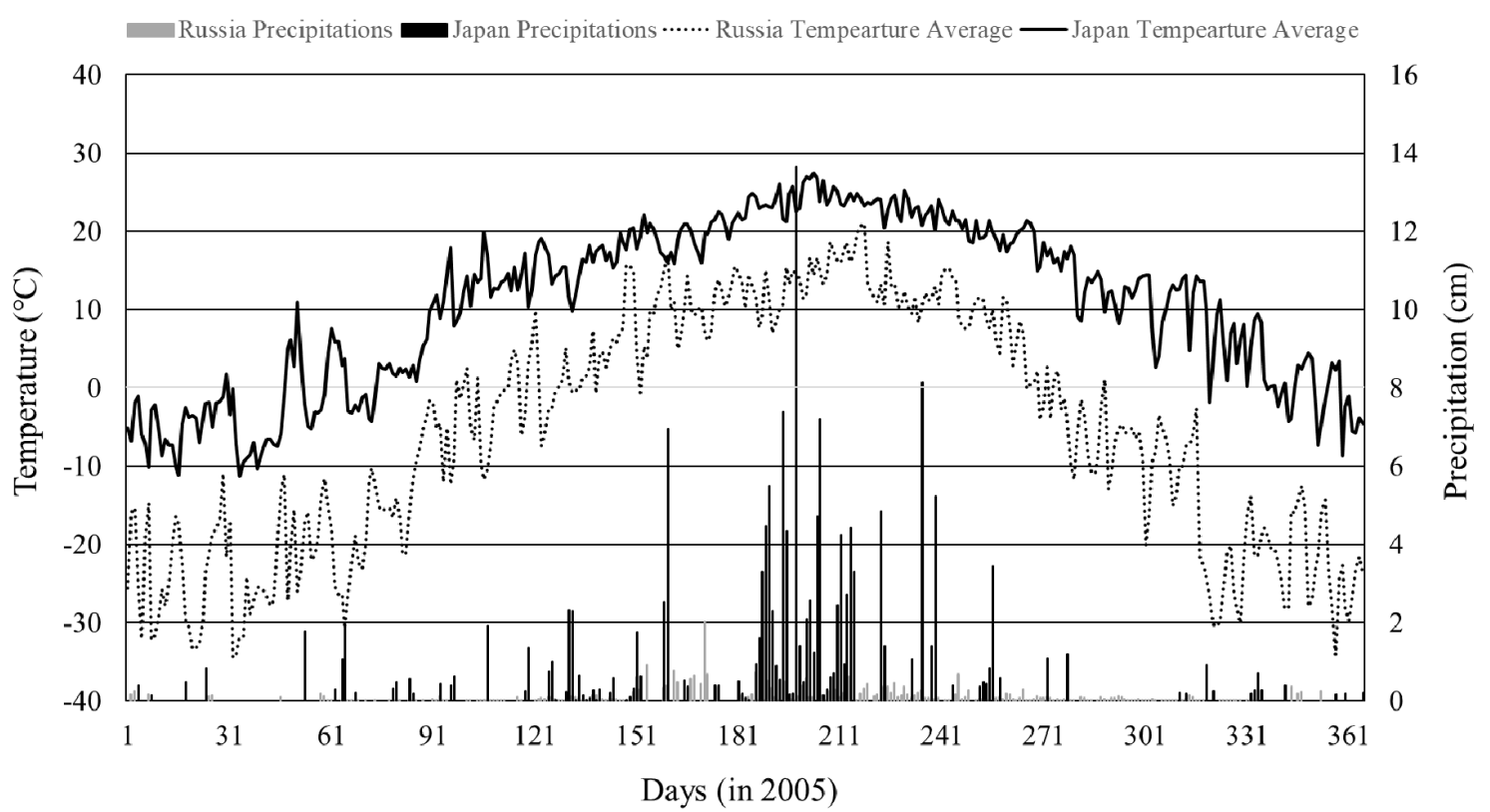

Figure 2. Climatic characteristics of the northernmost site (Buryatia, Russia) and the southernmost site (Kasuya, Japan) in 2005.

\section{Results}

\subsection{GSV and NPP}

From the BGC-MAN simulations, the estimated values of the GSVs of oak forests in Kasuya (Japan), Gwangneung (South Korea), Seolmacheon (South Korea), Sohung (North Korea), and Bikinsky (Russia) were 410, 511, 154, 65, and $153 \mathrm{~m}^{3} \mathrm{ha}^{-1}$, respectively, in 2005. The GSVs of pine forests in Gwangneung (South Korea), Wonsan (North Korea), Honghuaerji (China), Oblast (Russia), and Pribaykalsky (Russia) were $392,145,147,282$, and $124 \mathrm{~m}^{3} \mathrm{ha}^{-1}$, respectively, during the same period. The GSVs of larch forests in Laoshan (China), Tsenkhermandal (Mongolia), Khentei (Mongolia), Yeravninsky (Russia), and Buryatia (Russia) were 127, 156, 150, 227, and $116 \mathrm{~m}^{3} \mathrm{ha}^{-1}$, respectively (Figure 3). 


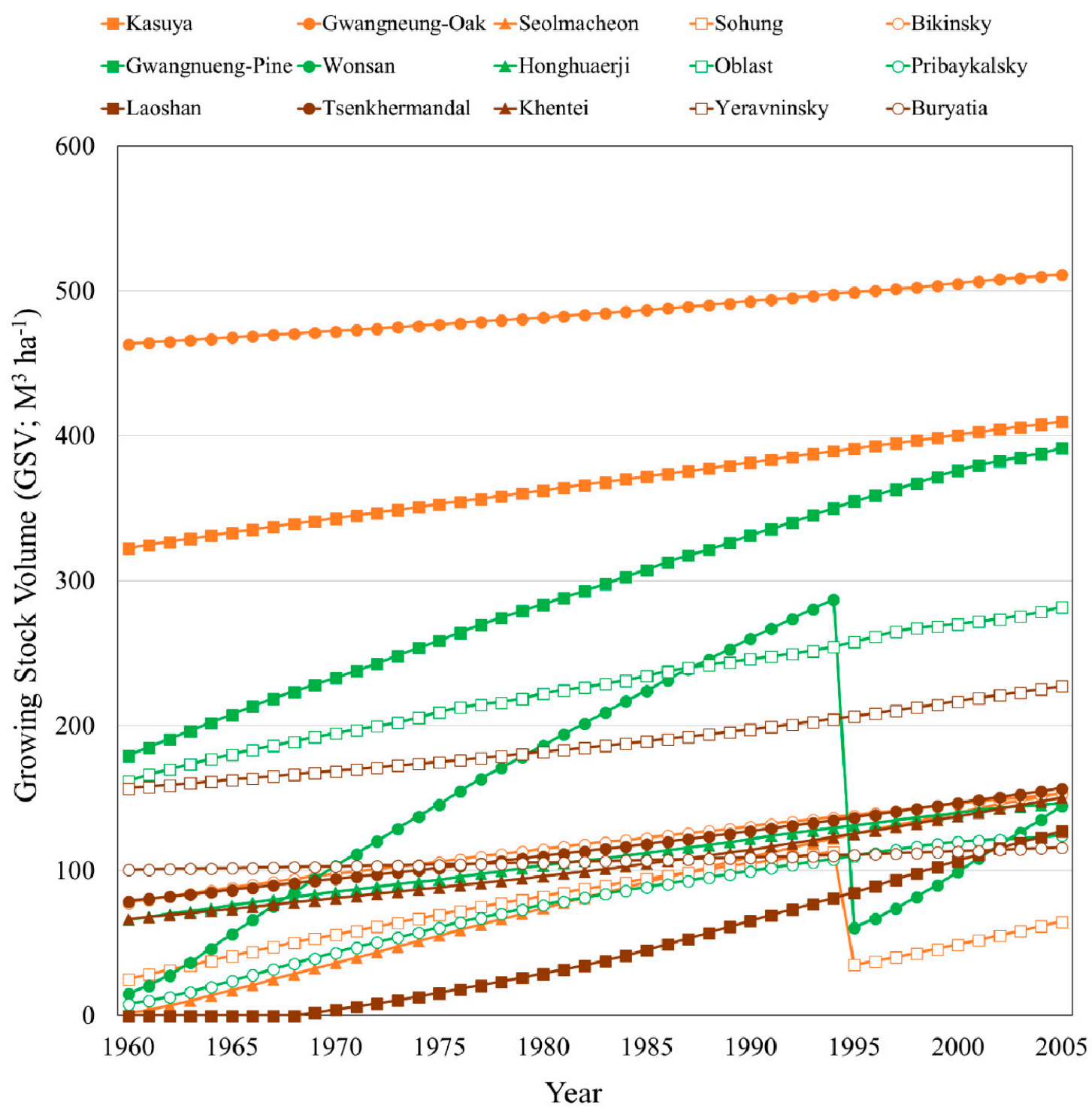

Figure 3. Growing stock volume (GSV) estimation through BGC-MAN simulations from 1960 to 2005.

Along the MLE in Northeast Asia, the GSV ranges were wide in the order of oak, pine, and larch forests. Protected forests showed much higher GSV, but GSVs in this region converged around $154 \mathrm{~m}^{3} \mathrm{ha}^{-1}$. Following the same order of sites among all forest types as for the GSV results, NPP values in oak forests were also estimated to be $5.05,5.39,5.22,4.18$, and $3.70 \mathrm{Mg} \mathrm{C} \mathrm{ha}^{-1}$, respectively, in 2005. The NPP values of pine forest sites were $6.39,6.75,2.68,3.49$, and $2.50 \mathrm{Mg} \mathrm{C} \mathrm{ha}^{-1}$, and the NPPs of larch forests were $5.24,1.12,1.35,1.27$, and $0.49 \mathrm{Mg} \mathrm{C} \mathrm{ha}^{-1}$, respectively (Figure 4). 


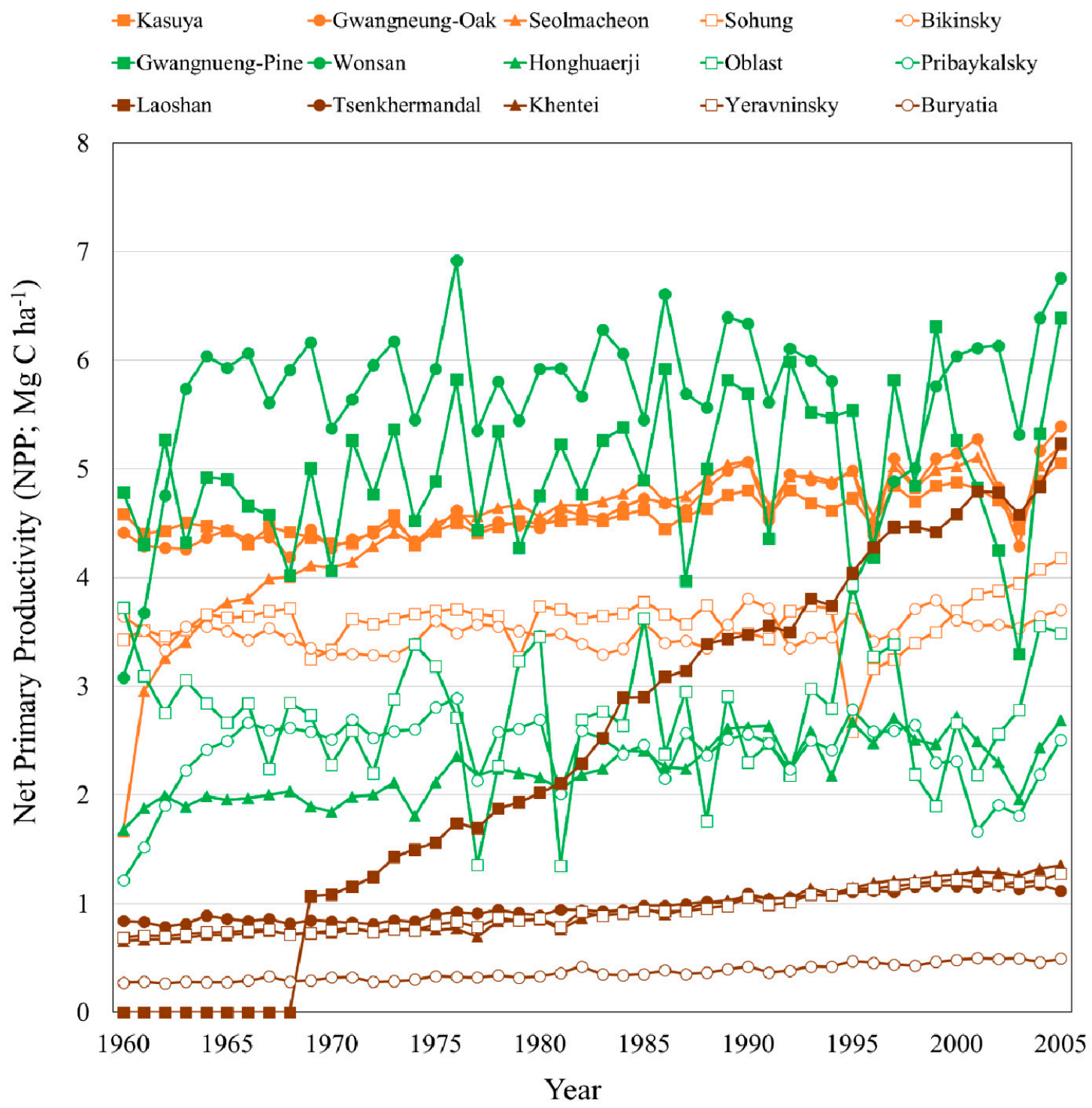

Figure 4. Net primary productivity (NPP) estimation through BGC-MAN from 1960 to 2005.

\subsection{Comparing with the Literature}

The estimated GSV and NPP values from the self-initialized model were compared with the previous literature. Many field studies, as well as modeling results for GSV and NPP, were available for some of our study sites, so we could compare our results with them directly. We obtained GSV and NPP values from previous reports if the data were available, however, we also assumed the values from diameter at breast height (DBH), gross primary productivity (GPP), and stand height in order to overcome the data limitation.

For the oak forests, the forest volume of Kasuya (Japan) was estimated at around 109-516 $\mathrm{m}^{3} \mathrm{ha}^{-1}$, when considering some old forest stands. To estimate the value, we obtained the DBH and stand density from JaLTER and Inoue et al. (2008) [35,69], and applied the biomass expansion equation from the National Institute of Forest Science (NIFoS), Republic of Korea [70]. The tree volume of oak forests in Gwangneung (South Korea) was around $550 \mathrm{~m}^{3} \mathrm{ha}^{-1}$ [36], and estimated annual NPP was 4.30-6.70 Mg C ha- [42,71]. In Seolmacheon (South Korea), we could estimate the tree volume from the DBH on National Forest Inventory (NFI) data, which was around 78-159 $\mathrm{m}^{3} \mathrm{ha}^{-1}$ [43]. In addition, using the hydrology model named RHESSys (Regional Hydro-Ecological Simulation System), we calculated GPP as 11.93-13.96 Mg C ha-1 [72]. Sohung (North Korea) is one of the 
reforestation areas in North Korea, and a previous study assumed some forest characteristics, however, it estimated a forest volume of around 56-66 $\mathrm{m}^{3} \mathrm{ha}^{-1}$ during 1989-2013 [45]. Bikinsky (Russia) is located in Far East Russia near the Chinese border. The forest volume here was estimated at around $154 \mathrm{~m}^{3} \mathrm{ha}^{-1}$, and annual NPP at $5.05 \mathrm{Mg} \mathrm{C} \mathrm{ha}^{-1}$.

The tree volume of the Gwangneung (South Korea) pine forest was estimated from a previous DBH survey at around 378-645 $\mathrm{m}^{3} \mathrm{ha}^{-1}$, and a National forest inventory (NFI) plot located near the site indicated $270 \mathrm{~m}^{3} \mathrm{ha}^{-1}$ [38]. The predicted annual NPP was 5.37-7.20 Mg C ha-1 [48]. Wonsan (North Korea), which was deforested and subsequently reforested, has an annual NPP range of 4.30-6.03 $\mathrm{Mg} \mathrm{C} \mathrm{ha}^{-1}$ based on the VISIT model simulation [16]. The forest volume of Honghuaerji (China) was estimated as 117-173 $\mathrm{m}^{3} \mathrm{ha}^{-1}$ [50]. In the case of Oblast (Russia), the forest volume was estimated at around $282 \mathrm{~m}^{3} \mathrm{ha}^{-1}$, and annual NPP was estimated at around $3.06 \mathrm{Mg} \mathrm{C} \mathrm{ha}^{-1}$. The GSV of forests in Pribaykalsky (Russia) was reported to be around $102 \mathrm{~m}^{3} \mathrm{ha}^{-1}$, and this forest's NPP was predicted to be $2.72 \mathrm{Mg} \mathrm{C} \mathrm{ha}^{-1}$.

For the larch trees of Laoshan (China), which are part of an experimental forest, GSV was estimated at around $117.86 \mathrm{~m}^{3} \mathrm{ha}^{-1}$ in 2001, therefore a GSV value exceeding $133.36 \mathrm{~m}^{3} \mathrm{ha}^{-1}$ would be expected in 2005 [73]. Other model simulations estimated the 300-year cumulated NPP to be 215.4-236.6 $\mathrm{kg} \mathrm{m}^{-2}$, which can be converted to 7.18-7.89 $\mathrm{Mg} \mathrm{C} \mathrm{ha}^{-1}$ [26], but these estimations have big variations, as these were young forest stands. The GPP of the forest in Khentei (Mongolia) was reported to be around 5.62-6.10 $\mathrm{Mg} \mathrm{C} \mathrm{ha}^{-1}$ [24], and the GSV was estimated to be $64-146 \mathrm{~m}^{3} \mathrm{ha}^{-1}$ via tree ring survey [52,53]. The forest volume of Yeravninsky was reported to be $227 \mathrm{~m}^{3} \mathrm{ha}^{-1}$, and annual GPP as 3.38 Mg C ha-1. In Buryatia (Russia), the forest volume was estimated to be $117 \mathrm{~m}^{3} \mathrm{ha}^{-1}$, and annual GPP as $2.81 \mathrm{Mg} \mathrm{C} \mathrm{ha-1}^{-1}$ (Table 3).

Table 3. Comparing BGC-MAN simulations and previous literature.

\begin{tabular}{|c|c|c|c|c|c|}
\hline Types & Simulation & Literature & Sources & Species & Locations \\
\hline \multirow{12}{*}{$\begin{array}{c}\text { GSV } \\
\left(\mathrm{m}^{3} \mathrm{ha}^{-1}\right)\end{array}$} & 410 & $109-516$ & Estimation $[35,69,70]$ & Oak & Kasuya \\
\hline & 511 & 550 & Chae (2011) [36] & Oak & Gwangneung \\
\hline & 154 & 78-159 & Kwon et al. (2009) [43] & Oak & Seolmacheon \\
\hline & 65 & $56-66$ & Piao et al. (2016) [45] & Oak & Sohung \\
\hline & 153 & 154 & Shvidenko et al. (2008) [46] & Oak & Bikinsky \\
\hline & 391 & $378-645$ & Noh et al. (2013) [38] & Pine & Gwangneung \\
\hline & 146 & $117-173$ & Zhu et al. (2003) [50] & Pine & Honghuaerji \\
\hline & 282 & 282 & Shvidenko et al. (2008) [46] & Pine & Oblast \\
\hline & 124 & 102 & Shvidenko et al. (2008) [46] & Pine & Pribaykalsky \\
\hline & 127 & $118-133$ & Shi et al. (2001) [73] & Larch & Laoshan \\
\hline & 227 & 227 & Shvidenko et al. (2008) [46] & Larch & Yeravninsky \\
\hline & 116 & 117 & Shvidenko et al. (2008) [46] & Larch & Buryatia \\
\hline \multirow{10}{*}{$\begin{array}{c}\mathrm{NPP} \\
\left(\mathrm{MgC} \mathrm{ha}^{-1}\right)\end{array}$} & 4.28 & $4.30-6.05$ & Lim et al. (2003) [71] & Oak & Gwangneung \\
\hline & 5.39 & $4.00-6.55$ & Lim et al. (2010) [42] & Oak & Gwangneung \\
\hline & 3.70 & 5.05 & Shvidenko et al. [46] & Oak & Bikinsky \\
\hline & 6.39 & $5.37-7.20$ & Eum et al. (2005) [48] & Pine & Gwangneung \\
\hline & 6.75 & $4.30-6.03$ & Cui et al. (2014) [16] & Pine & Wonsan \\
\hline & 3.49 & 3.06 & Shvidenko et al. (2008) [46] & Pine & Oblast \\
\hline & 2.50 & 2.72 & Shvidenko et al. (2008) [46] & Pine & Pribaykalsky \\
\hline & 5.23 & $7.18-7.89$ & Kondo et al. (2013) [26] & Larch & Laoshan \\
\hline & 1.28 & 3.38 & Shvidenko et al. (2008) [46] & Larch & Yeravninsky \\
\hline & 0.49 & 2.81 & Shvidenko et al. (2008) [46] & Larch & Buryatia \\
\hline GPP & 8.72 & $11.93-12.06$ & Shin et al. (2012) [72] & Oak & Seolmacheon \\
\hline$\left(\mathrm{MgC} \mathrm{ha}^{-1}\right)$ & 2.85 & $5.62-6.10$ & Takagi et al. (2015) [24] & Larch & Khentei \\
\hline
\end{tabular}


Furthermore, the simulated NPPs were compared with the Moderate Resolution Imaging Spectroradiometer (MODIS)'s NPP (MOD17A3H) product from the National Aeronautics and Space Administration (NASA), the United States [74]. Since the MOIDIS NPP product data are available from 2000 and our study has the BGC-MAN results until 2005, the six years of overlapping NPP results were compared to find the relationship (Figure 5).

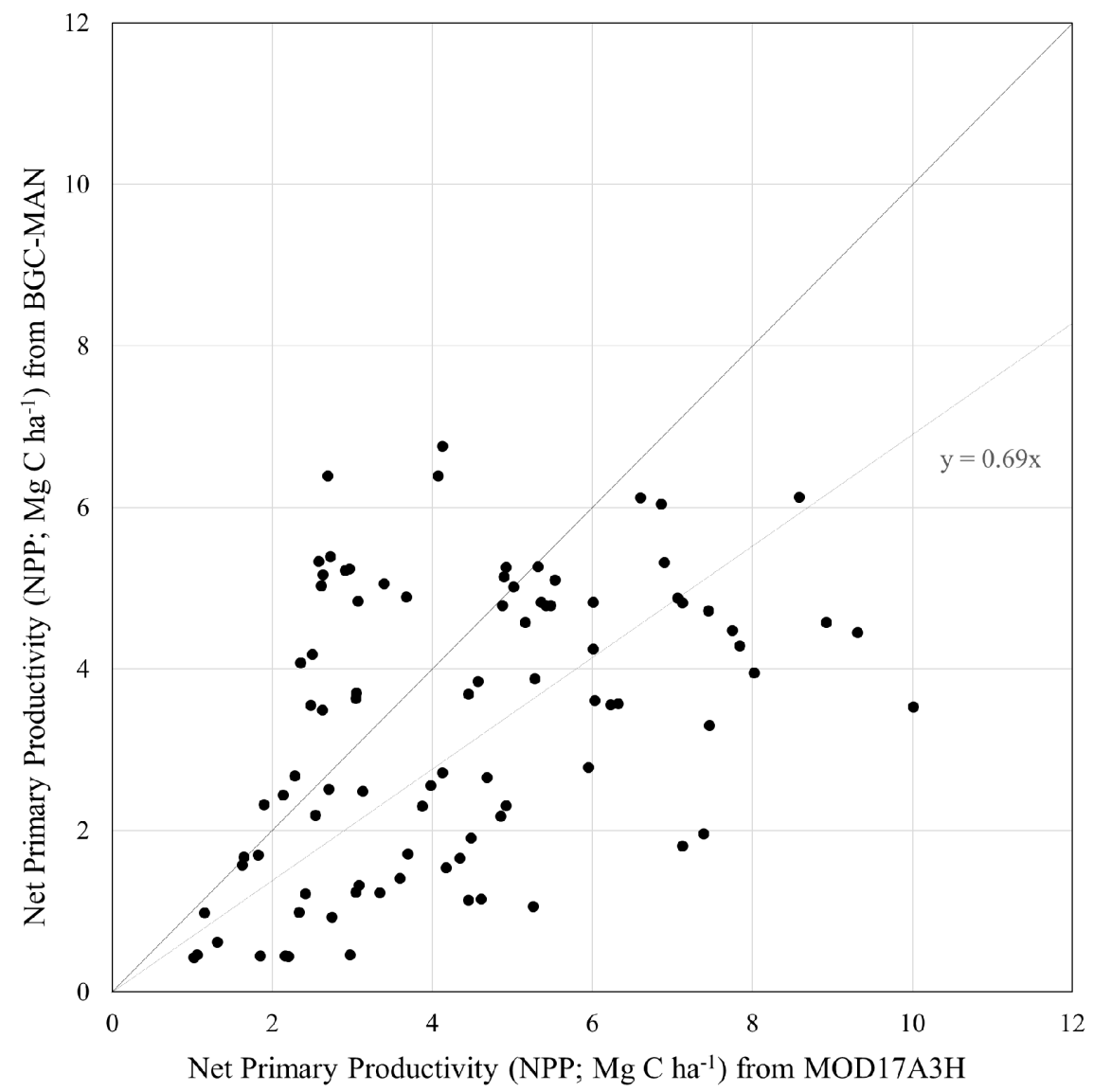

Figure 5. Relationship between the net primary productivities (NPPs) from MOD17A3H and BGC-MAN.

The NPP from the BGC-MAN simulation with climatic variations and the MODIS NPP from different characteristics of spectral reflectance may vary from time to time, but overall, they showed a positive correlation. The BGC-MAN results were underestimated compared to the NPPs from the MODIS NPP product, and the variations were shown in some larch forests because there was under estimation of the NPP from BGC-MAN.

\section{Discussion}

We identified changes to the forest ecosystems in the Northeast Asian MLE, and these results can explain some ecological transitions there. Under these transitions, we need to resolve expected problems through appropriate forest management and social efforts. The ecological transitions in the MLE of Northeast Asia are apparent from the annual rates of change of the forest volume and NPP. These values were estimated for a total of 15 sites under different environmental conditions and different forest management activities, and the simulation results were quite different according to latitude, site conditions, and climatic variations. At the species level, the overall BGC-MAN results from pine and oak forest sites were quite acceptable, even though we used parameterizations from European pine and oak forests to simulate P. sylvestris, Q. robur, and Q. petraea agg. characteristics here $[31,33,34,62,75]$, however, there were some instances of under or over estimation. These BGC-MAN parameters were effective for P. densiflora and the other oak tree species in the MLE of the Northeast Asia. The GSVs of 
larch forests from Laoshan, Tsenkhermandal, Khentei, and Buryatia were quite similar to previous reports, but the estimated NPP was very low. This implies that, although our simulations were already based on modified biomass allocation parameters, the European parameters of L. decidua need to be adjusted further for the simulation of L. Mongolica and L. Sibirica [10,76]. This variation might be caused by some ecotypes and ecoregions on the high mountains $[9,52,77]$. With the heavy wind and cold temperature, larch forests in Mongolia and Russia were differentiated in stomatal conductance and the tree root system in comparison with European larch forests and larch forests in China and the Northern Korean Peninsula.

Another reason for these variations in larch forests could be the over estimation of forest fires in the self-initialized model. We assumed values for depicting forest fires, GSV, and NPP based on an inventory [46], and there might be differences in spatial resolution between the published reports and modeling stands. This means that the statistics aggregate the effect of forest disturbance and management, but the model was directly affected by the initialized parameters. When we use a process-based ecosystem model, the model usually simplifies environmental changes $[10,78]$. Furthermore, the model was self-initialized, so the generalization of established parameters would be limited in specific ecosystems [62]. Therefore, the model requires more adjustments in order to be suitable for application in specific ecosystems. However, the historical information of the sites was limited, and this gave rise to difficulties in the first initialization of the model. Therefore, more detailed management and human intervention data in a site-specific manner will be required in future research to apply the model to specific sites with greater accuracy.

For the study sites subjected to simulations in this study, the reported NPP values along the Northeast Asian MLE were 7.21 Mg C ha ${ }^{-1}$ for Mt. Jumbong, South Korea [79]; 5.16-8.04 Mg C ha-1 around the Korean Peninsula [16]; 2.04-6.20 Mg C ha-1 along the border of the Korean Peninsula and China [80]; 3.23 Mg C ha-1 for the boreal forests (L. gmelinii) of China [81]; $2.45 \mathrm{Mg} \mathrm{C} \mathrm{ha}^{-1}$ for the larch forests of Eastern Siberia [82]; and 6.34 Mg C ha-1 among the East Asian regions, including our study area [23]. These estimated values also showed similar trends to our simulation results, which indicated a lower NPP at higher latitudes, although there were some limitations for larch forests. In particular, because the forest changed from temperate to boreal forest, these climatic influences are important for estimating ecosystem productivity [83,84]. In addition, there were many reports that MODIS NPPs were overestimated in Mid-Latitude region, so variations in NPP can be understood as general states [16]. In some forest stands without deforestation, such as in North Korea, the actual forest ecosystem's productivity will be more positive than our simulations, for which we assumed dramatic deforestation and forest degradation due to logging for energy and food production $[13,15]$. Therefore, we found that the BGC-MAN was effective in explaining not only ecological and social transitions of forests in the MLR of Northeast Asia but could also explain future estimations under various scenarios of afforestation, if the parameters and other site-specific information were available.

\section{Conclusions}

Through our synthetic study, we aimed to elucidate the process of applying the BGC-MAN in the MLE of Northeast Asia, and we applied the model to oak, pine, and larch forests. There were some limitations, but the parameterizations of oak and pine species from European species were acceptable in similar ecosystems in the Northeast Asian MLE when we compared the simulated results of forest NPP and GSV with literature values. However, the parameterizations for the larch species, which were distributed over the entire study region, need to be modified to be as specific as possible for the different forest sites. Overall, our simulations were representative of the differences in NPP and GSV by latitude, parameter, and climatic variations, although there were limitations due to the self-initialized model and insufficient data in this region. Under this complexity, the results explained the changes in ecosystem along the latitudinal (vertical) ecological transects as well as the effects of differences in forest management under the model uncertainties. Therefore, we can conclude that the BGC-MAN is suitable for application in this region, especially for oak and pine forests, and it also can represent 
the different management regimes among the different regions studied. Therefore, our results can contribute to future research attempting to apply the BGC-MAN and process-based ecological models in the MLE of Northeast Asia.

Author Contributions: C.S., S.A.P., A.S. developed overall concept and methodology. C.S., S.A.P conducted analysis, M.K., S.C., E.P processed data. D.S., F.K., W.-K.L. supervised overall research. F.K., W.-K.L. supported fund for the research. All authors gave comments to improve and read the final manuscript.

Funding: This study was funded by the Ministry of Environment (MOE) of the Republic of Korea (Project Number: 2014001310008) and was carried out with the support of ‘R\&D Program for Forest Science Technology (Project No. 2017044B00-1919-BB01 and Project No. 2018133B10-1820-BB01)' provided by Korea Forest Service (Korea Forestry Promotion Institute).

Acknowledgments: This study was developed in the Young Scientists Summer Program (YSSP) at the International Institute for Systems Analysis (IIASA), Laxenburg, Austria with support from the National Research Foundation (NRF), Republic of Korea.

Conflicts of Interest: The authors declare no conflict of interest.

\section{References}

1. Soja, A.J.; Tchebakova, N.M.; French, N.H.F.; Flannigan, M.D.; Shugart, H.H.; Stocks, B.J.; Sukhinin, A.I.; Parfenova, E.I.; Chapin, F.S.; Stackhouse, P.W. Climate-induced boreal forest change: Predictions versus current observations. Glob. Planet. Chang. 2006, 56, 274-296. [CrossRef]

2. Cowie, A.L.; Orr, B.J.; Castillo Sanchez, V.M.; Chasek, P.; Crossman, N.D.; Erlewein, A.; Louwagie, G.; Maron, M.; Metternicht, G.I.; Minelli, S.; et al. Land in balance: The scientific conceptual framework for Land Degradation Neutrality. Environ. Sci. Policy 2018, 79, 25-35. [CrossRef]

3. Bai, Z.G.; Dent, D.L.; Olsson, L.; Schaepman, M.E. Proxy global assessment of land degradation. Soil Use Manag. 2008, 24, 223-234. [CrossRef]

4. Neilson, R.P. Transient ecotone response to climatic change: Some conceptual and modelling approaches. Ecol. Appl. 1993, 3, 385-395. [CrossRef] [PubMed]

5. Moon, J.; Lee, W.K.; Song, C.; Lee, S.G.; Heo, S.B.; Shvidenko, A.; Kraxner, F.; Lamchin, M.; Lee, E.J.; Zhu, Y.; et al. An Introduction To Mid-Latitude Ecotone: Sustainability and Environmental Challenges. Sib. J. For. Sci. 2017, 53, 41-53.

6. Song, C.; Kim, S.J.; Moon, J.; Lee, S.J.; Lee, W.; Kim, N.; Wang, S.W.; Lee, W.K. Classification of global land development phases by forest and GDP changes for appropriate land management in the mid-latitude. Sustainability 2017, 9, 1342. [CrossRef]

7. Lamchin, M.; Lee, W.K.; Jeon, S.W.; Wang, S.W.; Lim, C.H.; Song, C.; Sung, M. Long-term trend and correlation between vegetation greenness and climate variables in Asia based on satellite data. Sci. Total Environ. 2018, 618, 1089-1095. [CrossRef] [PubMed]

8. Shvidenko, A.; Buksha, I.; Krakovska, S.; Lakyda, P. Vulnerability of Ukrainian forests to climate change. Sustainability 2017, 9, 1152. [CrossRef]

9. Choi, Y.; Lim, C.H.; Ryu, J.; Jeon, S.W. Bioclimatic classification of Northeast Asia reflecting social factors: Development and characterization. Sustainability 2017, 9, 1137. [CrossRef]

10. Ueyama, M.; Ichii, K.; Hirata, R.; Takagi, K.; Asanuma, J.; MacHimura, T.; Nakai, Y.; Ohta, T.; Saigusa, N.; Takahashi, Y.; et al. Simulating carbon and water cycles of larch forests in East Asia by the BIOME-BGC model with AsiaFlux data. Biogeosciences 2010, 7, 959-977. [CrossRef]

11. Park, M.S. Inter-Korean forest cooperation 1998-2012: A policy arrangement approach. Sustainability 2015, 7, 5241-5259. [CrossRef]

12. Bae, J.S.; Joo, R.W.; Kim, Y.S. Forest transition in South Korea: Reality, path and drivers. Land Use Policy 2012, 29, 198-207. [CrossRef]

13. Lee, S.G.; Choi, H.A.; Yoo, H.; Song, C.; Cha, S.; Bae, S.W.; Son, Y.; Lee, W.K. Restoration plan for degraded forest in the democratic people's Republic of Korea considering suitable tree species and spatial distribution. Sustainability 2018, 10, 856. [CrossRef]

14. Kang, S.; Choi, W. Forest cover changes in North Korea since the 1980s. Reg. Environ. Chang. 2014, 14, 347-354. [CrossRef] 
15. Kim, D.; Lim, C.H.; Song, C.; Lee, W.K.; Piao, D.; Heo, S.; Jeon, S. Estimation of future carbon budget with climate change and reforestation scenario in North Korea. Adv. Sp. Res. 2016, 58, 1002-1016. [CrossRef]

16. Cui, G.; Lee, W.K.; Kim, D.; Lee, E.J.; Kwak, H.; Choi, H.A.; Kwak, D.A.; Jeon, S. Estimation of forest carbon budget from land cover change in South and North Korea between 1981 and 2010. J. Plant Biol. 2014, 57, 225-238. [CrossRef]

17. Feng, L.; Jia, Z.; Li, Q. The dynamic monitoring of aeolian desertification land distribution and its response to climate change in northern China. Sci. Rep. 2016, 6, 1-10. [CrossRef]

18. Tsogtbaatar, J. Deforestation and reforestation needs in Mongolia. For. Ecol. Manag. 2004, 201, 57-63. [CrossRef]

19. Wenhua, L. Degradation and restoration of forest ecosystems in China. For. Ecol. Manag. 2004, $201,33-41$. [CrossRef]

20. Huang, L.; Xiao, T.; Zhao, Z.; Sun, C.; Liu, J.; Shao, Q.; Fan, J.; Wang, J. Effects of grassland restoration programs on ecosystems in arid and semiarid China. J. Environ. Manag. 2013, 117, 268-275. [CrossRef]

21. Schaphoff, S.; Reyer, C.P.O.; Schepaschenko, D.; Gerten, D.; Shvidenko, A. Tamm Review: Observed and projected climate change impacts on Russia's forests and its carbon balance. For. Ecol. Manag. 2016, 361, 432-444. [CrossRef]

22. Potapov, P.; Hansen, M.C.; Stehman, S.V.; Loveland, T.R.; Pittman, K. Combining MODIS and Landsat imagery to estimate and map boreal forest cover loss. Remote Sens. Environ. 2008, 112, 3708-3719. [CrossRef]

23. Matsushita, B.; Tamura, M. Integrating remotely sensed data with an ecosystem model to estimate net primary productivity in East Asia. Remote Sens. Environ. 2002, 81, 58-66. [CrossRef]

24. Takagi, K.; Hirata, R.; Ide, R.; Ueyama, M.; Ichii, K.; Saigusa, N.; Hirano, T.; Asanuma, J.; Li, S.G.; Machimura, T.; et al. Spatial and seasonal variations of CO2flux and photosynthetic and respiratory parameters of larch forests in East Asia. Soil Sci. Plant Nutr. 2015, 61, 61-75. [CrossRef]

25. Ueyama, M.; Kai, A.; Ichii, K.; Hamotani, K.; Kosugi, Y.; Monji, N. The sensitivity of carbon sequestration to harvesting and climate conditions in a temperate cypress forest: Observations and modeling. Ecol. Model. 2011, 222, 3216-3225. [CrossRef]

26. Kondo, M.; Ichii, K.; Ueyama, M.; Mizoguchi, Y.; Hirata, R.; Saigusa, N. The role of carbon flux and biometric observations in constraining a terrestrial ecosystem model: A case study in disturbed forests in East Asia. Ecol. Res. 2013, 28, 893-905. [CrossRef]

27. Churkina, G.; Running, S.W.; Schloss, A.L. Comparing global models of terrestrial net primary productivity (NPP): The importance of water availability. Glob. Chang. Biol. 1999, 5, 46-55. [CrossRef]

28. Li, B.; Wang, W. Trade-offs and synergies in ecosystem services for the Yinchuan Basin in China. Ecol. Indic. 2018, 84, 837-846. [CrossRef]

29. Merganičová, K.; Pietsch, S.A.; Hasenauer, H. Testing mechanistic modeling to assess impacts of biomass removal. For. Ecol. Manag. 2005, 207, 37-57. [CrossRef]

30. Choi, S.; Lee, W.K.; Kwak, H.; Kim, S.R.; Yoo, S.; Choi, H.A.; Park, S.; Lim, J.H. Vulnerability assessment of forest ecosystem to climate change in Korea using MC1 model. J. For. Plan. 2011, 16, 149-161.

31. Pietsch, S.A. Modelling Ecosystem Pools and Fluxes. Implementation and Application of Biogeochemical Ecosystem Models; Institute of Silviculture Department of Forest and Soil Sciences University of Natural Resources and Life Sciences (BOKU): Vienna, Austria, 2014.

32. Thornton, P.E.; Law, B.E.; Gholz, H.L.; Clark, K.L.; Falge, E.; Ellsworth, D.S.; Goldstein, A.H.; Monson, R.K.; Hollinger, D.; Falk, M.; et al. Modeling and measuring the effects of disturbance history and climate on carbon and water budgets in evergreen needleleaf forests. Agric. For. Meteorol. 2002, 113, 185-222. [CrossRef]

33. Pietsch, S.A.; Hasenauer, H.; Thornton, P.E. BGC-model parameters for tree species growing in central European forests. For. Ecol. Manag. 2005, 211, 264-295. [CrossRef]

34. Akujärvi, A.; Shvidenko, A.; Pietsch, S.A. Modelling the impacts of intensifying forest management on carbon budget across a long latitudinal gradient in Europe. Environ. Res. Lett. 2018, 14, 034012. [CrossRef]

35. Ishihara, M.I.; Suzuki, S.N.; Nakamura, M.; Enoki, T.; Fujiwara, A.; Hiura, T.; Hoshino, D.; Homma, K.; Hoshizaki, K.; Ida, H.; et al. Forest stand structure, composition, and dynamics in 34 sites over Japan. Ecol. Res. 2011, 26, 1007-1008. [CrossRef]

36. Chae, N. Annual variation of soil respiration and precipitation in a temperate gorest (Quercus serrata and Carpinus laxiflora) under East Asian monsoon climate. J. Plant Biol. 2011, 54, 101-111. [CrossRef] 
37. Wang, H.M.; Saigusa, N.; Zu, Y.G.; Wang, W.J.; Yamamoto, S.; Kondo, H. Carbon fluxes and their response to environmental variables in a Dahurian larch forest ecosystem in northeast China. J. For. Res. 2008, 19, 1-10. [CrossRef]

38. Noh, N.J.; Kim, C.; Bae, S.W.; Lee, W.K.; Yoon, T.K.; Muraoka, H.; Son, Y. Carbon and nitrogen dynamics in a Pinus densiflora forest with low and high stand densities. J. Plant Ecol. 2013, 6, 368-379. [CrossRef]

39. Crowther, T.W.; Glick, H.B.; Covey, K.R.; Bettigole, C.; Maynard, D.S.; Thomas, S.M.; Smith, J.R.; Hintler, G.; Duguid, M.C.; Amatulli, G.; et al. Mapping tree density at a global scale. Nature 2015, 525, 201-205. [CrossRef]

40. Kummu, M.; Varis, O. The world by latitudes: A global analysis of human population, development level and environment across the north-south axis over the past half century. Appl. Geogr. 2011, 31, 495-507. [CrossRef]

41. Tran, H.; Iida, S.; Inoue, S. Initial sprouting of some tree species in natural forests following 9-month cutting in Kasuya Research Forest of Kyushu University Forest, Japan. J. Fac. Agric. Kyushu Univ. 2005, 50, 471-480.

42. Lim, H.J.; Lee, Y.H.; Kwon, H. Evaluation of Community Land Model version 3.5-Dynamic global vegetation model over deciduous forest in Gwangneung, Korea. Korean J. Agric. For. Meteorol. 2010, 12, 95-106. [CrossRef]

43. Kwon, H.; Lee, J.; Lee, Y.; Lee, J.W.; Jung, S.W.; Kim, J. Seasonal variations of evapotranspiration observed in a mixed forest in the Seolmacheon catchment. Korean J. Agric. For. Meteorol. 2009, 11, 39-47. [CrossRef]

44. Shin, H.J.; Park, G.A.; Park, M.; Kim, S.J. Projection of forest vegetation change by applying future climate change scenario MIROC3.2 A1B. J. Korean Assoc. Geogr. Inf. Stud. 2012, 15, 64-75. [CrossRef]

45. Piao, D.; Zhu, Y.; Piao, D.; Lee, W.; Zhu, Y.; Kim, M.; Song, C. Assessment of forest degradation and carbon storage for REDD+ project in North Korea. Korean J. Environ. Biol. 2016, 9999, 1-7. [CrossRef]

46. Shvidenko, A.; Schepaschenko, D.; Nilsson, S.; Bouloui, Y. Tables and Models of Growth and Productivity of Forests of Major Forest Forming Species of Northern Eurasian; Federal Agency of Forest Management; International Institute for Applied Systems Analysis: Moscow, Russia, 2008.

47. Noh, N.J.; Son, Y.; Lee, S.K.; Yoon, T.K.; Seo, K.W.; Kim, C.; Lee, W.K.; Bae, S.W.; Hwang, J. Influence of stand density on soil CO2efflux for a Pinus densiflora forest in Korea. J. Plant Res. 2010, 123, 411-419. [CrossRef] [PubMed]

48. Eum, S.; Kang, S.; Lee, D. A simulation study to investigate climatic controls on net primary production (NPP) of a rugged forested landscape in The Mid-western Korean Peninsula. Korean J. Agric. For. Meteorol. 2005, 7, 67-78.

49. Hanns Seidel Foundation German-North Korean Cooperation in the Field of Forestry. Available online: https:// korea.hss.de/en/news/detail/german-north-korean-cooperation-in-the-field-of-forestry-news3931/ (accessed on 12 January 2019).

50. Zhu, J.; Zhi-ping, F.; Zeng, D.; Jiang, F.; Matsuzaki, T. Comparison of stand structure and growth between artificial and natural forests of Pinus sylvestiris var.mongolica on sandy land. J. For. Res. 2003, 14, 103-111.

51. Chen, Z.; Zhang, X.; Cui, M.; He, X.; Ding, W.; Peng, J. Tree-ring based precipitation reconstruction for the forest-steppe ecotone in northern Inner Mongolia, China and its linkages to the Pacific Ocean variability. Glob. Planet. Chang. 2012, 86-87, 45-56. [CrossRef]

52. Khishigjargal, M.; Dulamsuren, C.; Leuschner, H.H.; Leuschner, C.; Hauck, M. Climate effects on interand intra-annual larch stemwood anomalies in the Mongolian forest-steppe. Acta Oecol. 2014, 55, 113-121. [CrossRef]

53. Dulamsuren, C.; Khishigjargal, M.; Leuschner, C.; Hauck, M. Response of tree-ring width to climate warming and selective logging in larch forests of the Mongolian Altai. J. Plant Ecol. 2014, 7, 24-38. [CrossRef]

54. Dulamsuren, C.; Hauck, M.; Leuschner, H.H.; Leuschner, C. Climate response of tree-ring width in Larix sibirica growing in the drought-stressed forest-steppe ecotone of northern Mongolia. Ann. For. Sci. 2011, 68, 275-282. [CrossRef]

55. Kim, M.; Lee, W.K.; Choi, G.M.; Song, C.; Lim, C.H.; Moon, J.; Piao, D.; Kraxner, F.; Shvidenko, A.; Forsell, N. Modeling stand-level mortality based on maximum stem number and seasonal temperature. For. Ecol. Manag. 2017, 386, 37-50. [CrossRef]

56. Holland, E.A.; Dentener, F.J.; Bobby, H.; Sulzman, J.M. Contemporary and pre-industrial global reactive nitrogen budgets. Biogeochemistry 1999, 46, 7-43. [CrossRef] 
57. Vet, R.; Artz, R.S.; Carou, S.; Shaw, M.; Ro, C.U.; Aas, W.; Baker, A.; Bowersox, V.C.; Dentener, F.; Galy-Lacaux, C.; et al. A global assessment of precipitation chemistry and deposition of sulfur, nitrogen, sea salt, base cations, organic acids, acidity and $\mathrm{pH}$, and phosphorus. Atmos. Environ. 2014, 93, 3-100. [CrossRef]

58. Granhall, U.; Lindberg, T. Nitrogen fixation in some coniferous forest ecosystems. Ecol. Bull. 1978, 26, 178-192.

59. Todd, R.L.; Meyer, R.D.; Waide, J.B. Nitrogen Fixation in a Deciduous Forest in the South-Eastern United States. Source Ecol. Bull. 1978, 26, 114-121.

60. Son, Y. Non-symbiotic nitrogen fixation in forest ecosystems. Ecol. Res. 2001, 16, 183-196. [CrossRef]

61. Shugalei, L.S.; Vedrova, E.F. Nitrogen pool in northern-Taiga larch forests of central Siberia. Biol. Bull. 2004, 31, 200-208. [CrossRef]

62. White, M.A.; Thornton, P.E.; Running, S.W.; Nemani, R.R. Parameterization and sensitivity analysis of the BIOME-BGC Terrestrial Ecosystem Model: Net primary production controls. Earth Interact. 2000, 4, 1-85. [CrossRef]

63. Thornton, P.E.; Running, S.W. An improved algorithm for estimating incident daily solar radiation from measurements of temperature, humidity, and precipitation. Agric. For. Meteorol. 1999, 93, 211-228. [CrossRef]

64. Warszawski, L.; Frieler, K.; Huber, V.; Piontek, F.; Serdeczny, O.; Schewe, J. The Inter-Sectoral Impact Model Intercomparison Project (ISI-MIP): Project framework. Proc. Natl. Acad. Sci. USA 2014, 111, 3228-3232. [CrossRef] [PubMed]

65. Hempel, S.; Frieler, K.; Warszawski, L.; Schewe, J.; Piontek, F. A trend-preserving bias correction -The ISI-MIP approach. Earth Syst. Dyn. 2013, 4, 219-236. [CrossRef]

66. Rosenzweig, C.; Elliott, J.; Deryng, D.; Ruane, A.C.; Müller, C.; Arneth, A.; Boote, K.J.; Folberth, C.; Glotter, M.; Khabarov, N.; et al. Assessing agricultural risks of climate change in the 21st century in a global gridded crop model intercomparison. Proc. Natl. Acad. Sci. USA 2014, 111, 3268-3273. [CrossRef] [PubMed]

67. Kira, T. A New Classification of Climate in Eastern Asia as the Basis for Agricultural Geography; Horticultural Institute, Kyoto University: Kyoto, Japan, 1945.

68. Choi, S.; Lee, W.; Kwak, D.; Lee, S.; Son, Y.; Lim, J.; Saborowski, J. Predicting forest cover changes in future climate using hydrological and thermal indices in South Korea. Clim. Res. 2011, 49, 229-245. [CrossRef]

69. Inoue, T.; Enoki, T.; Tashiro, N.; Sakuta, K.; Inoue, S. Effects of topography and planted trees on the distribution of naturally regenerated broad-leaved trees in a 140-year-old Cryptomeria japonica plantation in northern Kyushu, Japan. J. For. Res. 2008, 13, 365-371. [CrossRef]

70. Son, Y.M.; Kim, R.H.; Lee, K.H.; Pyo, J.K.; Kim, S.W.; Hwang, J.S.; Lee, S.J. Carbon Emission Factors and Biomass Allometric Equations by Species in Korea; National Institute of Forest Science: Seoul, Korea, 2014.

71. Lim, J.; Shin, J.H.; Jin, G.Z.; Chun, J.H.; Oh, J.S. Forest stand structure, site characteristics and carbon budget of the Kwangneung Natural Forest in Korea. Korean J. Agric. For. Meteorol. 2003, 5, 101-109.

72. Shin, H.J.; Park, M.J.; Kim, S.J. Evaluation of forest watershed hydro-ecology using measured data and RHESSys Model 2014for the Seolmacheon catchment. J. Korea Water Resour. Assoc. 2012, 45, 1293-1307. [CrossRef]

73. Shi, F.; Chen, X.; Wang, W.; Takagi, K.; Akibayashi, Y.; Sasa, K.; Uemura, S. Vegetation characteristics of a Larch-dominant Site for CO2 flux monitoring study at the laoshan experimental station in northesast China. Eurasian J. For. Res. 2001, 3, 55-67.

74. MOD17A3 MODIS/Terra Gross Primary Productivity Yearly L4 Global 1 km SIN Grid; NASA EOSDIS Land Processes DAAC. 2011. Available online: https://lpdaac.usgs.gov/products/mod17a3v055/ (accessed on 10 February 2019).

75. Pietsch, S.A.; Hasenauer, H. Evaluating the self-initialization procedure for large-scale ecosystem models. Glob. Chang. Biol. 2006, 12, 1658-1669. [CrossRef]

76. Kajimoto, T.; Matsuura, Y.; Sofronov, M.A.; Volokitina, A.V.; Mori, S.; Osawa, A.; Abaimov, A.P. Above- and belowground biomass and net primary productivity of a Larix gmelinii stand near Tura, central Siberia. Tree Physiol. 1999, 19, 815-822. [CrossRef]

77. Kharuk, V.I.; Ranson, K.J.; Im, S.T.; Dvinskaya, M.L. Response of Pinus sibirica and Larix sibirica to climate change in southern Siberian alpine forest-tundra ecotone. Scand. J. For. Res. 2009, 24, 130-139. [CrossRef]

78. Kang, S.; Lim, J.H.; Kim, E.S.; Cho, N. Modelling analysis of climate and soil depth effects on pine tree dieback in Korea using BIOME-BGC. Korean J. Agric. For. Meteorol. 2016, 18, 242-252. [CrossRef]

79. Kang, S.; Lee, D.; Lee, J.; Running, S.W. Topographic and climatic controls on soil environments and net primary production in a rugged temperate hardwood forest in Korea. Ecol. Res. 2006, 21, 64-74. [CrossRef] 
80. Wang, P.; Sun, R.; Hu, J.; Zhu, Q.; Zhou, Y.; Li, L.; Chen, J.M. Measurements and simulation of forest leaf area index and net primary productivity in Northern China. J. Environ. Manag. 2007, 85, 607-615. [CrossRef] [PubMed]

81. Gower, S.T.; Krankina, O.; Olson, R.J.; Apps, M.; Linder, S.; Wang, C. Net primary production and carbon allocation patterns of boreal forest ecosystems. Ecol. Appl. 2001, 11, 1395-1411. [CrossRef]

82. Sato, H.; Kobayashi, H.; Iwahana, G.; Ohta, T. Endurance of larch forest ecosystems in eastern Siberia under warming trends. Ecol. Evol. 2016, 6, 5690-5704. [CrossRef] [PubMed]

83. Shuman, J.K.; Shugart, H.H.; O'Halloran, T.L. Sensitivity of Siberian larch forests to climate change. Glob. Chang. Biol. 2011, 17, 2370-2384. [CrossRef]

84. Jiang, H.; Apps, M.J.; Zhang, Y.; Peng, C.; Woodard, P.M. Modelling the spatial pattern of net primary productivity in Chinese forests. Ecol. Model. 1999, 122, 275-288. [CrossRef]

(C) 2019 by the authors. Licensee MDPI, Basel, Switzerland. This article is an open access article distributed under the terms and conditions of the Creative Commons Attribution (CC BY) license (http://creativecommons.org/licenses/by/4.0/). 